\title{
NÄO TEMOS MEDO DAS AMEAÇAS DE GOLPE
}

Esta é a íntegra do discurso pronunciado ontem pelo senador Afonso Arinos:

"Sr. presidente, srs. constituintes, os nobres companheiros naturalmente compreenderăo a dificuldade com que ascendo a esta tribuna, dificuldade momentânea, que procuro, fazendo um esforço sobre mim mesmo, superar e afastar, mas nobre dificuldade, porque năo vem da inteligencia, vem do coração.

Foi a recepção, o incitamento, o apoio, o estímulo com que a Assembleia Nacional Constituinte, pela sua visf́vel maioria, me impeliu a esta tribuna, tendo, por delegação, e assumindo a pesada responsabilidade de representar os constituintes do PMDB, do PTB, do PDC, do Partido Comunista do Brasil, do Partido Comunista Brasileiro, do Partido Socialista do Brasil, toda a gama multicolorida do pensamento político, toda a biografia gloriosa de tantos companheiros que há tantos anos estão na luta pela liberdade e pela justiça no nosso país; de representar nesta tribuna, com a exceção de meu proprio partido, que aqui não assinou a lista que me concede poderes para falar em nome dele, mas creio que realmente também falo em nome dele. Falo em nome dele também. Pouco contam para mim as divergencias, as dissidencias e as dificuldades, supostas ou verdadeiras, que se apresentam ao caminho deste partido. Falo pela tradição gloriosa da Frente Liberal. Por ser frente, por ser liberal, por ser brasileira, por ser progressista, ela é parlamentarista.

Divirjo daqueles que pretendem representar esta posiçăo utilizando situaçōes pessoais e oficiais que nem sempre correspondem aos sentimentos das bases. Mas não insistirei neste caminho. 
O que vou fazer aqui é cumprir o mandato que me foi outorgado pela gama partidária do meu pais, que me foi outorgado pelo sentimento daqueles que morreram nas torturas da ditadura, pela luta daqueles que se empenharam na tribuna da liberdade durante a ditadura, por aqueles que escreveram e náo puderam ler o que escreviam pelos impedimentos da censura ditatorial civil e militar. Falo, aqui, em nome daqueles que formaram a minha mocidade $e$ junto a qual nasceram essas idéias, junto a qual acompanhei essas idéias, tendo eu mesmo mudado de posiçáo em momento importante da minha vida parlamentar, aquele momento em que deixei a defesa do presidencialismo, na qual tinha empenhado grande esforço na luta contra o glorioso Raul Pilla, para o qual peço uma salva de palmas em sua memória. Deixei esta luta, no passado, e percebi que năo era mais possivel, no Brasil, termos a ilusăo de que o sistema presidencial possa corresponder aos interesses e ao futuro do pais.

É lamentável que hoje, precisamente hoje, eu venha aqui, como tópico deste discurso - sr. presidente, pretendo exceder o tempo que me foi concedido, e peço a v. exa. que tenha bondade para comigo discutir as posiçoes tomadas por sua excelência, meu querido amigo, $o$ nobre presidente da República, nas declaraçōes que fez ontem ao chegar de uma viagem ao Nordeste. Săo coisas elementares, são enganos comuns, săo posiçōes absolutamente inverídicas, năo inverídicas no sentido moral, mas inverídicas no sentido factual, no sentido historico, aquelas que apresentou. Dizer que o pais năo pode enfrentar o sistema parlamentar porque năo tem partido é uma coisa que se choca violentamente com toda a história parlamentar do Brasil. No Brasil, so existiram partidos verdadeiramente autenticos e espontâneos que se formaram ao sabor das exigencias do parlamentarismo imperial. Os partidos nacionais so apareceram no Brasil depois que eles se tornaram internacionais fora do Brasil. Foi depois que se fundou o Partido Comunista do Brasil em 1922; foi depois que o Partido Integralista veio para o Brasil no sentido de combater as idéias do Partido Comunista, que começaram a aparecer os partido nacionais. Os partidos nacionais foram tentados implantar-se no Brasil inutilmente pelos homens mais fortes da República; foram tentados por Júlio de Castilho, no princípio da sua vida política - o grande líder gaúcho -; foram tentados por Pinheiro Machado com o Partido Republicano Conservador; foram tentados pelo maior homem que houve na República brasileira até hoje, Rui Barbosa, com o Partido Republicano Liberal; foram tentados várias vezes os partidos e nunca conseguiram ser partidos nacionais. Eram esses partidos estaduais, a serviço dos governos locais, arapucas de voto e balcao de vendas de empregos em todo o pais. Os partidos nacionais năo săo senáo isso: arapucas eleitorais e balcōes de vendas para os solicitadores de emprego.

Falar em falta de administraçăo, de poder administrativo, que o Brasil năo tem condiçóes administrativas para enfrentar o problema do parlamentarismo? S. exa., mais uma vez, meu velho amigo, meu querido amigo José Sàrney, se choca de frente com a verdade histórica. 
Quando foi que o sistema presidencial, no Brasil, organizou a vida administrativa? Quando foi que se estabeleceu aqui a justiça administrativa? Quando se houve aqui a prova de merito, o acesso nas carreiras? Os gabinetes estáo cheios, os ministérios estáo cheios, há milhoes e milhóes de funcionários públicos que pesam no orçamento federal. Náo estou contra eles, nunca fui contra eles, estou contra o sistema. Enquanto que nos paises parlamentaristas a maior prova da capacidade do serviço público e tradicionalmente o governo parlamentarista ingless, que enfrentou os bombardeios da Inglaterra sem que o ingles perdesse o Onibus para ir ao trabalho. Como e que se pode falar?

A Escola Nacional da Administraçăo Pública, na França, é uma das grandes glorias da ciencia administrativa no mundo. Ecole National de Administration Publique é a grande escola francesa. Todos os paises parlamentaristas se esmeram. Na Alemanha Ocidental, na Dinamarca, na Holanda, na Espanha e até em Portugal.

Em Portugal, o funcionário público - que é tratado como uma figura mais ou menos pitoresca por Eça de Queirós, em seus romances -, hoje a situaçáo administrativa no governo parlamentarista português é um modelo para nós, um modelo que nos entusiasma, e, digo com certa melancolia, que nos envergonha.

O presidente da República náo pode se ater a essas razóes quando trata de um assun to que esquece ou que não conhece; năo săo os argumentos que nos possam convencer, aqueles que nós temos que adotar, temos que defender, temos que sustentar, temos que impulsionar. Nos náo podemos mais fugir diante de promessas nem de ameaças. Năo podemos mais fugir! Temos que marchar contra as promessas da corrupçāo, da corrupçāo a que se pode proceder, que tem a in tençăo, que pode chegar a loucura de supor que pode influir nas decisoes deste plenário. Náo podemos fugir, nem diante das promessas, nem diante das ameaças. Não temos medo das ameaças de golpes armados.

No dia em que o Brasil vier a enfrentar, a colocar, a sustentar, a implantar o regime parlamentar, estará terminado o problema das ameaças neste pals. Temos que salvar o Brasil daquilo que ele é! Temos que fazer que ele deva ser aquilo que deve ser! Temos que enfrentar, temos que lutar! Não estamos em uma luta de conversaçóes, de sessóes. Nós náo estamos em uma luta de expedientes e de espertezas. Estamos em uma luta que é luta! Nós estamos em uma frente que é frente! Nós estamos com o peito, năo escondendo o coraçăo, mas exibindo-o! Não estamos com a nossa mente procurando caminhos esconsos para esconder o que pensamos. Nós temos que procurar os caminhos claros para firmar o que queremos. Temos que ganhar esta questáo. Nós temos que transformar esta Assembléia Nacional Constituinte, com todos os pesos que pareça decair sobre seus ombros, na única que fez a maior mudança na história do Brasil, desde que ele existe com independéncia.

Este caminho é o do governo parlamentar. Este caminho é o da 
emenda parlamentar. Queridos companheiros, patrfcios, amigos: coragem; desafio, marcha, vamos vencer, vamos implantar o parlamentarismo no Brasill.

(Publicado na Folha de S. Paulo, 31/out/1987) 